Фата А. Егановић

Универзитет у Новом Саду

Филозофски факултет

fataeganovic@yahoo.com doi: 10.19090/zjik.2018.87-96

UDK 821.163.41.09 Sremac S. оригинални научни рад

\title{
СТАРО ВРЕМЕ, НОВО ВРЕМЕ И МИТСКО ВРЕМЕ У ПРИПОВЕЦИ „КИР ГЕРАС" СТЕАВАНА СРЕМЦА
}

САЖЕТАК: Време (земан или вакат) у приповеци Стевана Сремца „Кир Герас” одвија се у три равни за које би се могло рећи да у себи носе извесне рефлексе народне књижевности, али и грчког мита. Те три равни су: митско време, старо време (које симболички представљају кир Наун и кир Герас) и ново време „пошљедње вријеме” (које представљају Герасова деца). У приповеци је евидентна конфронтација та два света, односно времена која доводи до смрти старог времена, и његовог васкрсавања у новом поретку кроз усаглашавање са њим. Под претпоставком да митско време, у овом случају, представља задату „космичку архепричу” о тој метаморфози света, према којој се ова друга времена усаглашавају, циљ је да се кроз пажљиво читање и анализу приповетке докаже и опише та „смена” кроз кризу старог времена сублимирану у судбини кир Гераса, односно начину на који он прихвата промену кроз лажну смрт и поновно рађање.

Кључне речи: Стеван Сремац, старо време, ново време, митско време, архетип

У приповеци Стевана Сремца под насловом „Кир Герас”, мотив времена има вишеструко значење. На плану приповедног тока, време представља, условно речено, симболички оквир унутар ког се одвија радња о животу кир Гераса Паскалиса (од раног детињства, преко младости и зрелог доба до дубоке старости). Већ у првом пасусу, након приказане слике погуреног старца, почетак приче се ретроспективно смешта у његово рано детињство:

...почећемо с оним његовим безазленим и раним добом кад је био још мали, што рекли, као песница, и кад још није ни сркнуо, а камоли се напио горчине из пехара који време точи и живот служи и нуди свакоме створу (Сремац 2011: 345).

\footnotetext{
${ }^{1}$ Рад је проистекао из испитне теме „Старо време, ново време и митско време у приповеци 'Кир Герас' Стевана Сремца” на курсу Рефлекси усмене књижевности у делу Стевана Сремца.
} 
У употреби мотива времена као оквира приповедног тока налази се симболичко изједначавање радње са животним циклусом једног човека. У том значењу је појам времена нека врста индикатора човекове смртности.

Време (земан или вакат) се, међутим, унутар приче (нарочито из перспективе лика кир Гераса) одвија у још три равни за које би се могло рећи да у себи носе извесне рефлексе народне књижевности - нарочито поетике темпоралног у народним епским песмама, односно, начина на које се време уклапа у ткиво њихове приче (Марија Клеут 2013: 393). Значења која се из тих равни активирају надилазе модерно схватање времена као протока живота. Ова значења укључују и време као свет, односно, његово устројство. Те три равни су: митско време, старо време и ново време (пошљедње време).

Митско време у „Кир Герасу” везује се за вилајет - реч турског порекла коју Герас и „београдски Јелини” користе у значењу отаџбина, односно, место одакле потичу. То је време такође старо, али друкчијег квалитета од, условно речено, историјског времена. Оно је потпуно сакрално, време обележено доста снажнијим утицајем „виших сила” на човека, како и каже у једном делу: „древно доба, кад се судбина и кивни богови окоме на неког и сруче му на слаба плећа и главу његову све беде овога света" (Сремац 2011: 382). У Герасовој причи о вилајету, препознаће се свет грчког мита, протресен кроз сито српске усмене књижевности, ${ }^{2}$ њене хришћанске матрице и исламских утицаја. ${ }^{3}$ То је могуће уочити у књигама које Герас чита (али и начину на који их перципира и касније интерпретира):

Недељом и празником ..... после подне је седео пред авлијским или дућанским вратима, па певушио, управо појао из Катавасије (наравно на грчком језику), или је читао крадом Грчку миологију, или читао јавно Житија светих која је добијао на прочитање и духовно созидање од свога даскала из грчке недељне школе, ћир-Харитона (Сремац 2011: $351)$.

Подсвесна мултикултурална рецепција античког мита, између осталог, свакако да представља стожер Сремчевог хумора у овој приповеци. То се лепо

\footnotetext{
${ }^{2}$ Од предања до елемената лирског и епског песништва.

${ }^{3}$ Од лексике (вилајет), до етичко-верских момената као што су значења „арам паре” и ,алал паре”: „Боље сиротиња са алалом, него богат са арамом.”
} 
види у одељку где кир Герас изражава негодовање због нерадног дана поводом Светог Саве као српског светитеља:

Србин да буде пустиножитељ, светац чудотворац, великомученик и угодник божији! Какво је чудо учинио? ... Ели убио аждају, како свети Ђорђије? Неје! ... Ели ишао сербез преко мору како по царски друм... како свети Николај? Неје... Ели је благословио маслину да буде дрво господње и проклео врбу да нема плода? Ели натерао ђавола да избљује шест поједене деце од сестру Мелелију, како свети Сисоје што уради? Неје! Неје!... Не може, зато неје!... Има ли Србин за то? Нема! (Сремац 2011: 354).

Овде, међутим, није реч само о хумору. Овде се ради о једном сложеном интегрисању најмање два митска мишљења (једног, који се налази у корену српског усменог стваралаштва; и другог, који извире као темељ старогрчких драмских облика - трагедије и комедије).

У том погледу нарочито је занимљив кир Герасов помен легенде о светом Сисоју, који као да је део сижеа једне народне скаске. У његовој основи се, међутим, очигледно налази митска прича о Кроносу који је појео сву своју децу $^{4}$ (Хада, Посејдона, Херу, Персефону, Хестију), осим Зевса, уместо ког Реа подмеће камен. Зевс касније долази и на превару служи Кроносу напитак који чини да овај поврати камен и пет богова. Ти богови (Зевс, Посејдон, Хад, Хера, Персефона и Хестија) након побуне, рата и свргавања оца начиниће нови поредак света. ${ }^{5}$ У контексту приче о старом и новом времену у приповеци, претпоставка је да Сремац није случајно убацио баш овај пример о Светом Сисоју који алудира на препознатљив грчки мит о новом поретку света који настаје када син (Зевс) свргне оца (Кроноса). Сремац је у овом примеру показао да ова два митска мишљења заправо суштински обједињава архајски концепт времена, по коме се свет периодично изнова ствара а време обнавља (Пешикан 2007: 143).

Животни век кир Гераса, описан у приповеци, заправо опонаша ову идејну путању метаморфозе света угравирану у митско време. Приповетка говори о смени два времена (света): старог (кир Наун и кир Герас) и новог (кир

\footnotetext{
${ }^{4}$ Којих је исто било шесторо.

${ }^{5}$ Који је, поред тога, био крај златног доба за човека, и почетак сребрног доба.
} 
Герасова деца: Аристотелос, Ксенофон, Милош и Љубица). У тој „смени” описана је и криза старог времена, сублимирана у судбини кир Гераса, односно начина на који он прихвата промен ${ }^{6}$ кроз лажну смрт и поновно рађање (попут Феникса). У својеврсном приповедном поступаку који Сремац примењује у овој приповеци, апсорбујући српску усмену културу и елементе античке митске традиције, има нечег од концепта бахтиновског поимања карневала:

У карневалу, аналогно архаичном празнику, коментарисани су кризни тернуци у природи, промена годишњих доба, а у људском постојању: рођење, венчање и смрт, односно умирање и васкрсавање, који су се смењивали, али не и искључивали и потирали. Зато ту негативно није одвајано од позитивног, већ се преко негације пружа опис метаморфозе света који пролази кроз своје различите фазе (Бахтин 1978: 428-429).

Старом времену, дакле, припадају кир Наум и кир Герас. Овај моменат откривамо у једном њиховом разговору из Герасовог шегртског периода, када му кир Наум, као изговор што га тако дуго држи за шегрта, као тобож старији, објашњава зашто мора служити седам, уместо десет година као у старо време:

... И зато, ето, говораше му ћир Наун, и он, Герас - као хришћанин и Јелин - треба равно седам година (ни дан мање, ни дан више) да служи! А то је и боже помози, причаше му ћир Наун, јер кад је он газда - био во времја оно шегрт у Москопољу, служио је као шегрт равних - не седам, као они данас - него десет година, јер су - тумачило се тада - десет заповеди божијих старије од свега на свету! ... Али, сад су, вели ћир Наун, друга времена; свет се покварио и од бога отпадио, и зато сада и он, Герас, служи само седам година, а оне три, додаје газда, однео је андрак и какадемон! (Сремац 2011: 350)

Кир Наун је тај који први помиње смену старог и новог времена. ${ }^{7}$ Интересантно је, међутим, и то што помиње свет који се „покварио и од бога отпадио" чиме симболички означава смену генерација. Значајно је што то чини алузијом на две варијанте песме „Свеци благо дијеле” (СНП II, 1 и 2) у којој бог и свеци, због људских сагрешења, доводе свет до уништења. У обе варијанте се након људског покајања свет обнавља, што нарочито добро

\footnotetext{
${ }^{6}$ Кроз своју лажну, из ове перспективе, ритуалну смрт.

${ }^{7}$ У остатку приче то ће свакако бити кир Герас.
} 
описују последњи стихови друге варијанте: „смилова се бог на сиротињу/ те се опет свијет наслиједи (СНП II, $1: 10){ }^{8}$

Пре него што се и у кир Герасовом времену „свијет наслиједи” од стране његових потомака, постојао је тај кризни период оличен у конфликту између старих (који представљају старо, добро, морално време) и младих (који су опет носиоци новог, лошег, исквареног, неморалног времена). И то кир Герас прилично оштроумно уочава:

Као Јелин, и паметан човек, он је наскоро увидео да је овде, између њега и синова му, сукоб између два правца, двојаког васпитања, сукоб две културе, и увидео је да се, како је да је, мора трпети, јер мора тако бити (Сремац 2011: 368).

Ново време не односи се само на биолошки млађу генерацију, већ и на нове идеје, нове концепте живота, односно рада и уживања. Те идеје углавном стижу као утицај Запада, према коме Стеван Сремац у већини дела управља своју сатиру.

Оно што из кир Герасове тачке гледишта изазива отпор према том новом, младом времену и његовим носиоцима, добрим делом је оправдано. Он види младе трговце који се лако задужују, а потеже тај дуг враћају, расипни су. И не само то. Интересантно је његово запажање о разлици у физичком изгледу старе и младе генерације трговаца и занатлија. Млађи се, у овом поређењу чине некако, физички слабији, чак феминизирани, у односу на генерацију очева:

Већ онако на око, па каква грдна разлика! Они стари носили на вилицама, јаким као жрвњи којима жрнају со, бакенбарде, а ови нови носе неке француске неозбиљне брадице, мале као запета у буквару. Они стари с отеченим рукама и грдним чворноватим ногама, масивни као вертхајмова каса, кад иду и гледају само преда се ... и на пола миље издалека ударају на мајоран и на харинге; а ови нови са ногама као у какве фине машамоде, витки и танки, као какав 'бренајзен' из будоара какве даме, кад иду зверају на све стране и погледају, и загледају и

\footnotetext{
${ }^{8}$ Ово нас, између осталог, упућује на паралелни темпорални континуитет божанског и људског времена који на готово идентичан начин функционише у грчком миту о Кроносу и у епској песми „Свеци благо дијеле”.
} 
даме, и питају се и шацују себи ако је девојка: колико доноси мираза; а ако је удата; је ли приступачна (Сремац, 2011: 370).

Осим физичке разлике, ту је и морална и етичка разлика: млади су непоуздани, реч им нема тежину, самим тим нема ни међусобног поверења: „Ја да имам пари... па да ти дадем у четири ока, на чес, како у стари земан даваше трговац трговцу, како у оно старо Гушино, Атулино и Кутулино време што беше - ама га сад нема онакво пријатељство и поштење једно (Сремац 2011: $372)$.

У поимању младих, новац је добио другачију вредност у односу на стару генерацију. Новац није роба која се размењује и чије управљање захтева мудрост, штедљивост и марљивост оличену у дугорочном и напорном раду. Новац је новој генерацији, пре свега, средство за задовољавање личних потреба. Самим тим је постало много важно да се до њега дође, а мање важно како ће се то реализовати.

Сходно томе, кир Герас постаје жртва некадашњег шегрта Пиносавца. Након преваре коју је доживео, а која је срушила сва његова уверења о стабилности и устројству старог времена, он доживљава подсмевање и осуду својих рођених синова. И тако, једно јутро изнад своје главе затиче мудрост никог другог до Вука Караџића: „Тешко ногама под лудом главом” (Сремац 2011: 375). И најзад, смрћу своје жене Евтерпије, кир Герас се као симбол старог времена повлачи, урушава, у чему можемо препознати ритуално умирање старог, свргнутог божанства од стране његових потомака.

Кир Герасова деца, нарочито синови, Аристотелос, Ксенофон и Милош, представници су тог новог (а сада из перспективе њиховог оца) последњег времена. Мотив последњег (апокалиптичног) времена присутан је у одређеном броју епских народних песама (навели смо пример песме „Свеци благо дијеле”, у обе своје варијанте). Иако постоје основе да се овај мотив на плану значења доведе у везу са Библијом (Пешикан 2007: 133), ${ }^{9}$ у овој Сремчевој приповеци он се симболички веже за архајски концепт времена, по коме се свет периодично изнова ствара а време обнавља (Пешикан 2007: 143).

До промене континуитета старог времена долази још од периода када кир Герас шаље своје синове на школовање у иностранство. Одлука је донета

\footnotetext{
${ }^{9}$ Крај света описан у књизи Новог Завета „Откровење Јованово”.
} 
под утицајем мајке Евтерпије која се бунила да деци са тако племенитим ,jелинским” именима буде намењена судбина простих бакалина. Тако да су у радњи задржали најмлађег сина Милоша (који нема племенито ,јелинско" име), а ова два послали у Праг и Беч да се образују.

Са две године студија, уз коментар кир Гераса „паметној глави доста и једно око!" (Сремац 2011: 366) Аристотелос и Ксенофон самоиницијативно се враћају кући. Они, међутим, долазе измењени. Евтерпијина импресија о синовима, из перспективе материнске љубави, крајње је интересантна за разматрање. Синови у њеној перцепцији (која се базира на релацијама из народне културе своје-туђе) спадају у „своје” које је искусило и прихватило утицај „туђег”. Е сад, када се њена реакција артикулише, добије се нарочита хуморна бравура коју је Сремац изузетно вешто извео. Овако Терпа види њихову трансформацију:

Ко је био тих првих дана срећнији од пресрећне мајке, Герасовице, посмарајући своје лепо израсле синове, са лепим светским манирима, фино обучене, како лепо говоре, и за време говора обрезују нокте, гладе их малом турпијом и чисте малом четкицом, а кад се изражавају, једанако вичу ‘молим’ и ‘пардон' ... Кад једу, они виљушку не држе у десној него у левој руци, а кад дође ред на грожђе, а они љуске пљују у тањир, а и руке после перу над тањиром. ... Кад се умивају, певају све неке аустријске песме, певају 'тра-ла-ла' или 'Oj, супе, шамбр сепаре!' Скачу, избацују руке, дижу столицу, чуче и дижу столицу, чуче и дижу се, и све такве фине ствари раде, што се мајци необично допада, само не воли кад јој се синови хвале како су у Трсту, у једној талијанској ресторацији, јели батака од жаба. То јој само још не иде у главу, и онда их моли да јој не причају такве ствари, ни њој, а још мање другима (Сремац 2011: 376-377).

Под утицајем браће, мења се и најмлађи син Милош. То кир Герас с негодовањем примећује. Каже да се носи као какав галантеријски калфа, има лаковане ципеле у којима се стално огледа. „Почео је да се маже неком помадом, па изгледа као миш кад упадне у маст” (Сремац 2011: 371).

Аристотелос и Ксенофон, током свог школовања у Прагу и Бечу, попримају хедонистички концепт западноевропске аристократије који је махом био заснован на луксузној доколици, којој свакако није могло бити места у трговачкој средини цинцарског гета у Београду, где је владала девиза: 
„Време је новац”, а новац се добијао радом, одговарајућом расподелом зарађених средстава и штедњом. Самим тим је правилна расподела времена између рада и одмора од рада била изнад свега. Доколица, као празно време изван контекста сакралног празничног времена, била је недопустива.

Бар за људе старог времена какав је био њихов отац, кир Герас. За разлику од своје жене, иако му није недостајало родитељске љубави, Герас није одобравао финоћу и светске манире које су Аристотелос и Ксенофан примењивали, нарочито када су они подразумевали пијанчења до касно у ноћ. Тако да је, најпре, употребио неинвазивне методе преваспитавања у виду изрека јелинских мудраца које им је качио у собу: „Време добро употреби.” (Сремац 2011: 368) и „Учи се време познавати; у времену свако добро лежи!” (Сремац 2011: 368).

Старо време (стари свет) и ново време (нови свет) представљају главне поларитете којима је обојена цела приповетка „Кир Герас”. Између та два поларитета постоји известан негативни набој, који кроз конфликт тежи ка свом разрешењу. Конфронтација та два света, односно времена, доводи до смрти старог времена, које потом васкрсава у новом поретку кроз усаглашавање са њим. Митско време, у овом случају, представља задату „космичку архепричу” о тој метаморфози света, према којој се ова друга времена усаглашавају.

Приповетка говори о смени два времена (света): старог (кир Наун и кир Герас) и новог (кир Герасова деца: Аристотелос, Ксенофон, Милош и Љубица). У тој „смени” описана је и криза старог времена, сублимирана у судбини кир Гераса, односно начина на који он прихвата промену кроз лажну смрт и поновно рађање:

Стари негдањи Герас Паскалис је - тако да кажем - капитулирао. И он је најзад одмахнуо руком, запливао струјом новога времена, која је многе и многе понела собом. 'На млађима свет остаје!' И он неће да је бела врана међу својима. Као нови феникс из пепела, тако се родио из старога кир Гераса Паскалиса нови Ђерасим Паскаљевић! (Сремац 2011: 388).

Судбина главног јунака приповетке - кир Гераса, опонаша идејну путању метаморфозе света угравирану у митско време и тиме, као што је тумачење показало, доводи у значењску везу мотив смене старог и новог времена присутних у миту о Кроносу, и мотив последњег времена у двема 
варијантама песме „Свеци благо дијеле” . Те се, стога, у овом делу Стевана Сремца могу констатовати, поред рефлекса српске народне књижевности, и рефлекси античког мита.

Писац је, претпоставимо, у овој сличности мотива осетио један те исти архетип који лежи у антагонизму старог и новог, старости и младости. Тај архетип у себи носи парадоксални подсвесни страх родитеља од деце, зато што она, без обзира на то што представљају продужетак човека као врсте, она су и подсетник (пророчанство) његове смртности као појединца (Mišel Fuko 1976: 124). С друге стране, последње време које долази услед накупљених грехова људи, покајањем се поново обнавља. У оба случаја неминовно долази до успостављања новог времена које се заснива на рушењем старог. Поларности ће остати супротне, али ће свакако доћи до неутралисања негативног набоја међу њима, што оставља простора кир Герасу да заплива у новом времену као поново рођен у својој новој животној улози.

\section{ЛИТЕРАТУРА}

Караџић, Вук Стефановић. 1988. Српске народне пјесме II (1845). Сабрана дела Вука Караџића V. (Прир. Радмила Пешић). Београд: Нолит.

Клеут, Марија. 2013. Време, земан или вакат у српскохрватским епским народним песмама. У: Делић, Л. 2013. Зборник радова. Аспекти времена у фолклору. књ. 8, Институт за књижевност и уметност. Београд: 393-404.

Освалт, Сабина. 1980. Грчка и римска митологија. Љубљана: Младинска књига.

Пешикан Љуштановић, Љиљана. 2007. „Пошљедње вријеме’ у Библији и песмама из Вукових збирки”. Станаја село запали: Огледи о усменој къижевности. Нови Сад, 2007, 133-43.

Сремац, Стеван. 2011. Кир Герас. У: Максимовић Г. 2011. Изабране приповетке. Нови Сад: БМС.

$* * *$

Bahtin, Mihail. 1978. Stvaralaštvo Fransoa Rablea i narodna kultura renesanse $i$ srednjeg veka. Beograd: Nolit.

Fuko, Mišel. 1976. Istorija seksualnosi, korišćenje ljubavnih uživanja. Prevela: Ana Jovanović-Kralj. Beograd: Prosveta. 
Fata A. Eganović

\section{OLD TIME, NEW TIME AND MYTHICAL TIME IN STEVAN SREMAC' SHORT STORY "KIR GERAS"}

\section{Summary}

Time ("zeman" or "vakat" in Turkish) in Stevan Sremac' short story "Kir Geras" seems to exist on three different levels. We can say that these levels contain in themselves a certain reflection of folk literature, as well as of the Greek myth. The three levels are: mythical time, old time (symbolically represented by Kir Naun and Kir Geras) and new time or "recent time" (represented by Geras' children). Old time (old world) and new time (new world) are the main polarities present throughout the entire short story. There is a kind of negative charge between these two polarities which, through conflict, strives towards a resolution. The confrontation of these two worlds leads to the death of old time which is then resurrected in the new world order through harmonizing with it. Mythical time, in this case, is a given "cosmic archetype of a story" about the world's metamorphosis, and two other types of Time align themselves according to the archetype. Thus, this "shift" describes the crisis of old time sublimated in the fate of Kir Geras which imitates the path of the world's metamorphosis engraved in the abovementioned mythical time. In that manner, as this analysis has shown, Geras's fate puts forward the significance and meaning of the relationship between the motif of the shift from old to new time present in the myth of Chronos and the motif of recent time in two versions of the poem "Sveci blago dijele". Therefore, apart from the reflections of Serbian folk literature, the reflections of the Greek myth are to be identified in this Stevan Sremac' short story as well.

Keywords: Stevan Sremac, old time, new time, mythical time, archetype 